\title{
Cretaceous isochron ages of K-Ar system in the UHP metamorphic rocks of the Tso Morari dome, western Himalaya, India
}

\author{
Chitaro Gouzu†*, Tetsumaru Itaya† and Talat Ahmad§ \\ † Graduate School of Science and Technology, Kobe University, Kobe 1-1 Rokkodai-cho, Nada, Kobe 657-8501, JAPAN \\ Present address: Hiruzen Institute for Geology \& Chronology, 161-1 Sai, Okayama 703-8248, JAPAN \\ ¥ Research Institute of Natural Sciences, Okayama University of Science, 1-1 Ridai-cho, Okayama 700-0005, JAPAN \\ $\$$ Wadia Institute of Himalayan Geology, 33, G.M.S. Road, Dehradun 248001, INDIA
}

*To whom correspondence should be addressed.E-mail: gouzu@geohiruzen.co.jp

\begin{abstract}
Ultrahigh-pressure metamorphic (UHPM) rocks occur commonly in continent-continent collision type orogenic belts and their mineral assemblages indicate the formation at the depth of $100 \mathrm{~km}$ and more. Since Chopin (1984), the geology and petrology of the UHPM rocks have been studied well to estimate their P-T histories at ca. 20 localities in the world. However, the geochronological approaches to estimate time of events, especially exhumation, are still not well successful. In UHPM rocks and the associated high-pressure metamorphic (HPM) rocks of many metamorphic sequences, discordant K$\mathrm{Ar}$ and Ar/Ar age relations have been reported, probably caused by the excess ${ }^{40} \mathrm{Ar}$. To reveal exhumation history of UHPM rocks, phengite and paragonite, separated from UHPM rocks from the Tso Morari dome (TMD), western Himalaya, India, are analyzed with K-Ar and Ar/Ar methods.
\end{abstract}

The authors applied an isochron method to the UHPM rocks of which the host lithologies were continental materials having potential excess ${ }^{40} \mathrm{Ar}$. Then petrology and geochronology of UHPM rocks from Tso Morari dome ( $50 \mathrm{~km} \mathrm{x} 100 \mathrm{~km})$, western Himalaya, India were examined. The lithology, which is thought to be margin of Indian continent, consists of eclogites, and basic and pelitic schists, which are closely associated with each other. Recently, Sachan et al. (2001) discovered coesite from an eclogite block. The authors collected the three types of rocks from an area (ca. $20 \mathrm{~km} \mathrm{x} 15 \mathrm{~km}$ ) of the Tso Morari dome where coesite has been found, and calcschist and basic schist from the adjacent Indus suture zone, which is the boundary between Eurasian and Indian continents. Eclogite having Grt+Omp+Ca$\mathrm{amp}+\mathrm{CzO}+\mathrm{Phn}+\mathrm{Rtl} \pm \mathrm{Pg} \pm \mathrm{Chl} \pm \mathrm{Cc}$ occurs only in the core of meterscale mafic rock lenses, which were intercalated with the pelitic schists. This suggests that the coexisted mafic and pelitic rocks have suffered the UHPM and the same P-T-t history. The smaller mafic lenses and pelitic rocks were heavily retrograded and have mineral assemblages of $\mathrm{Ca}-\mathrm{Amp}+\mathrm{CzO}+\mathrm{Bt}+\mathrm{Chl}+\mathrm{Ab}+\mathrm{Cc}+\mathrm{Tnt}$ $\pm \mathrm{Phn} \pm$ Grt (relict) \pm Rtl and $\mathrm{Qtz}+\mathrm{Phn}+\mathrm{Ab}+\mathrm{Tnt}+\mathrm{Zrn} \pm \mathrm{Pg} \pm \mathrm{Chl} \pm$ $\mathrm{Grt} \pm \mathrm{Bt} \pm \mathrm{Ap} \pm \mathrm{CzO} \pm \mathrm{Kfs} \pm \mathrm{Cc}$, respectively.

Examined were the representative samples collected from eclogites (TM810 and TM214), basic schists (TM702, TM1006) and peltic schists (TM205, TM706, TM1003, TM1012, TM1015, TM1207 and TM1209), and from calcshists (TM1401 and TM1402). Eclogite sample TM214 has pseudomorph of coesite as inclusion of garnet. Phengites are common in eclogites and pelitic schists which sometimes have paragonite. The basic schists, which have sometimes biotite, contain rarely phengite and paragonite. Phengites have significantly different chemistry between the eclogite and pelitic schists, being due to difference of bulk chemistry of rocks. Phengites in pelitic schists show variable $\mathrm{Si} / \mathrm{Al}$ and $\mathrm{Na} / \mathrm{K}$ ratios in a thin section and even in a

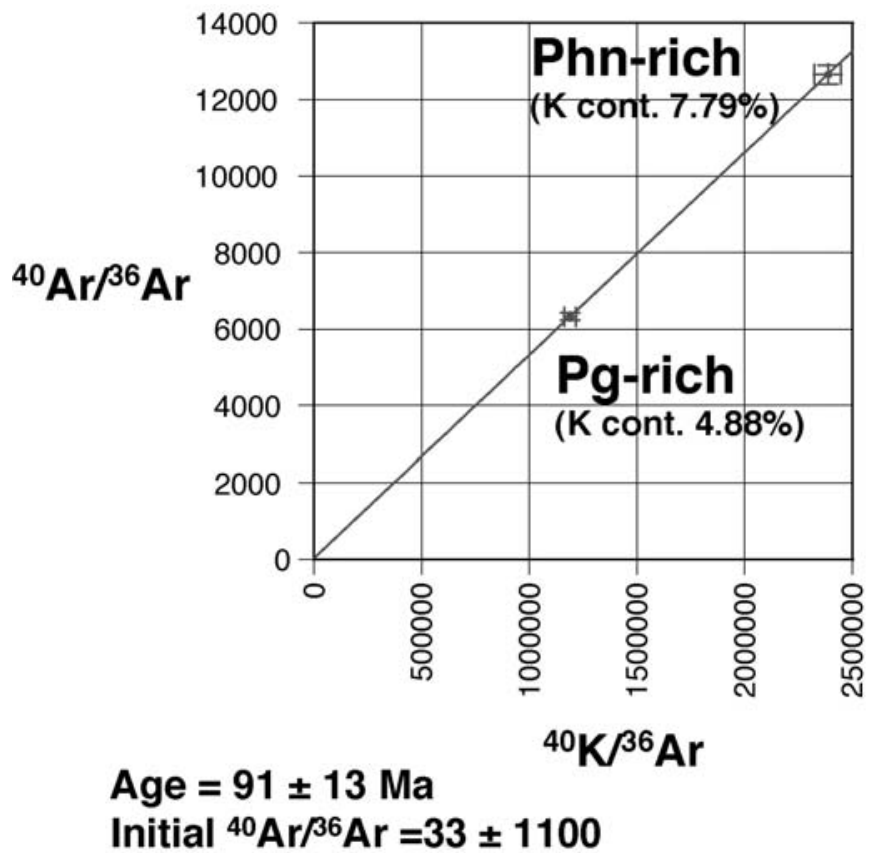

FIGURE 1. Isochron diagram and calculated age using data obtained from K-analyses of two different mineral fractions collected from a pelitic schist (TM205)

single crystal, which indicating retrograde metamorphism. Biotites are homogeneous. K-Ar analyses were carried out on phengite (50 to $87 \mathrm{Ma}$ ) from pelitic schists and biotite (96 and $134 \mathrm{Ma}$ ) from the basic schists in the Tso Morari dome, indicating variety of ages. Phengites from calcshists in the Indus suture zone were 40 and 43 Ma. Pelitic schist TM205 has paragonite and phengite, giving $84 \mathrm{Ma}$ in paragonite - phengite mixture $(\mathrm{K}=4.9$ wt. \%) and $85 \mathrm{Ma}$ in phengite rich fraction (K=7.8 wt. \%). The isochron age using the two data sets is $91 \pm 13 \mathrm{Ma}$. Eclogite TM810 having phengite and paragonite were analyzed by laser probe Ar/Ar method. Ar/Ar step-heating analyses using single phengite crystal showed the age spectra having 130 to $170 \mathrm{Ma}$ fractions and with a plateau of $132 \mathrm{Ma}$ defined by $80 \%$ of total gas released. $\mathrm{Ar} / \mathrm{Ar}$ spot dating results using a thin section were 124 and 145 Ma from phengites, and 77 and $155 \mathrm{Ma}$ from paragonites. The isochron age using the four data sets is $143 \pm 34$ Ma with an initial ratio of $166 \pm 110$, and the age using the two data sets, which have relatively small errors in age and diagram, is $111 \pm 53 \mathrm{Ma}$ with an initial ratio of $736 \pm 830$. 
The Tso Morari dome has also been studied with other chronological methods, giving a Lu-Hf mineral age of $55 \pm 12 \mathrm{Ma}$ (De Sigoyer et al. 2000), a Sm-Nd mineral age of $55 \pm 7 \mathrm{Ma}$ (De Sigoyer et al. 2000) and a SHRIMP U-Pb zircon age of $48 \pm 1 \mathrm{Ma}$ (Leech et al. 2003) as the timing of eclogite-facies metamorphism. These previous ages are consistent with phengite K-Ar phengite ages of the calcschists from the Indus suture zone. Their ages may not be the timing of UHPM because they do not have any feature of UHPM for the geochronological system and the ages are inconsistent with the isochron age from the eclogite (111 and $143 \mathrm{Ma}$ ) and from the pelitic schist (91 Ma).

\section{References}

Chopin C. 1984. Coesite and pure pyrope in high-grade blueschists of the western Alps: a first record and some consequences. Contrib Mineral Petrol 86:107-118

De Sigoyer J, V Chavagnac, J Blichert-Toft, IVilla, B Luais, S Guillot, M Cosca and G Mascle. 2000. Dating the Indian continental subduction and collisional thickening in the northwest Himalaya: Multichronology of the Tso Morari eclogites. Geology 28: 487-490

Leech M, S Singh, AK Jain and RM Manickavasagam. 2003. New U-Pb SHRIMP ages for the UHP Tso-Morari crystallines, eastern Ladakh, India. 2003 GSA abstract no. 260-24

Sachan HK, BK Mukherjee, Y Ogasawara, S Maruyama, AK Pandey, A Muko, $\mathrm{N}$ Yoshioka and H Ishida. 2001. Discovery of coesite from Indian Himalaya: consequences on Himalayan tectonics. UHPM Workshop 2001 at Waseda University abstract, 124-128 